\title{
Difference of Entrepreneurial Intention among Male and Female Undergraduates
}

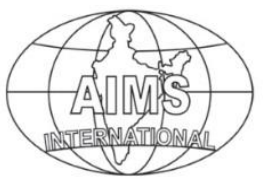

DOI: $10.26573 / 2020.14 .1 .3$

Volume 14, Number 1

January 2020, pp. 43-51

\author{
Randini S. Ranwala \\ University of Kelaniya \\ Kelaniya, Sri Lanka \\ (randinir@kln.ac.lk)
}

\begin{abstract}
The purpose of this study is to identify the difference of entrepreneurial intention based on the gender of Sri Lankan undergraduates. Current study is a cross sectional study conducted in the first half of the year 2019 using 300 undergraduates as the initial sample from three universities located in Sri Lanka using the stratified random sampling. Data was collected through a self-administered questionnaire. Conclusions have been derived based on the regression analysis and independent sample t-test where the results depicted a significant difference between male and female undergraduates in terms of entrepreneurial intention.
\end{abstract}

Keywords: Behavior, B2C, Online, Shopping, In Entrepreneurial Intention, Male, Female, Gender and Theory of Planned Behavior

\section{Introduction}

Sri Lanka is a developing country which is going through lots of economic problems like high inflation, less disposable income, unemployment etc. In order to eliminate this situation, Sri Lanka is having a burning need of entrepreneurs, who will provide employment to others and will help to increase productivity and disposable income.

Developing entrepreneurship is vital for any country because of the ability of creating self-employment and the ability of creating employment opportunities. To solve global development disparity, entrepreneurship has been identified as a key component (GEM, 2012). When talking about entrepreneurship, entrepreneurial intention is a major topic discussed in literature. Entrepreneurial intention has been discussed as an outcome variable in many prominent studies (Ferreira, Raposo, Rodrigues, Dinis, \& Do Paco, 2012).

In order to become an entrepreneur or to start a new venture, a person must have an idea about entrepreneurship (Edirisinghe \& Nimeshi, 2016). Since decades, researchers have been doing lot of researches using different factors as predictors of entrepreneurial intention. Majority of studies regarding entrepreneurial intention have used Theory of Planned behavior as the predictor of intention to become entrepreneur. Accordingly, this theory is a well-established theory in literature as a predictor of entrepreneurial intention.

Gender specific entrepreneurial behavior is now a popular debate in entrepreneurship literature. However, earlier literature on entrepreneurship did not discuss gender specific behavior (Brush, 2006). Later, researchers began to argue 
that findings on males are not applicable to females (Loscocco, Monnat, Moore, \& Lauber, 2009). Hence, in the process of entrepreneurship, gender has been a subject of interest for researchers (Zhang, et al., 2009; Bird \& Brush, 2002). Yet, those studies are depicting opposing results about the role of gender in entrepreneurship (Langowitz \& Minniti, 2007; Wilson, Kickul, \& Marlino, 2007). Some studies on entrepreneurial intention founded that difference in gender makes difference in entrepreneurial intention (Zhao, Seibert, \& Hills, 2005), while other studies have found that there is no difference in entrepreneurial intention among different genders (Gupta, Turban, Wasti, \& Skidar, 2009). For example, Fagenson \& Marcus, (1991) affirmed that entrepreneurship is mostly associated with masculine activities.

Many studies regarding entrepreneurial intention and gender described that, entrepreneurial intention of males is greater than that of females (Shinnar, Giacomin, $\&$ Janssen, 2012). Additionally, the gender specific barriers create fewer possibilities for women to involve in self-employment (Verheul, Thurik, Grilo, \& van der Zwan, 2012). Some other studies have highlighted that gender similarities are much higher than differences in entrepreneurship (Gupta, Turban, Wasti, \& Skidar, 2009; DiazGarcia \& Jimenez-Moreno, 2009). However, Social context is an important factor when studying the gender specific behavior (Welter, 2011).

Hence, current study talks about the entrepreneurial intention of male and female undergraduates in Sri Lanka.

In Sri Lanka, graduates are facing a high level of unemployment (see table 1) due to the fact that they are trying to find salaried employments. Though, government universities provide both management and entrepreneurship education for undergraduates, the universities are only able to produce less than 5\% of entrepreneurs (Perera, 2012). Therefore, there is a gap between the education and the real situation. Entrepreneurial intention is the base for entrepreneurial behavior. The individual decision to start a business venture has been seen as a fundamental milestone in the start-up process for long time (Linan \& Rodrıguez-Cohard, 2015).

Table 1 Unemployment Statistics

\begin{tabular}{|l|c|c|c|}
\hline Above A/L & $\mathbf{2 0 1 7}$ & $\mathbf{2 0 1 6}$ & $\mathbf{2 0 1 5}$ \\
\hline Male & 5.0 & 4.7 & 4.7 \\
\hline Female & 11.3 & 11.9 & 13.5 \\
\hline
\end{tabular}

Source: (Economic Statistics of Sri Lanka 2018, 2018)

Therefore in this research, I intend to understand the level of entrepreneurial intention of male and female undergraduates in Sri Lanka by assessing the impact of personal attitude, subjective norm and perceived behavioral control on the entrepreneurial intention of female undergraduates.

Inferences of this study will be useful to create fruitful policies to develop and groom graduate entrepreneurs in Sri Lanka with the assistance of education with regard to their gender. Educationists can use this study to create more effective curriculum which can help to develop entrepreneurship.

\section{Literature Review and Hypothesis Formulation}

Entrepreneurial intention is a widely discussed topic in literature and different scholars have defined it in different ways. Bird (1988) has defined entrepreneurial 
intention as the articulated behavior of individuals to be entrepreneurs. Hence, according to Crant (1996), it is the individual's judgement on starting a new venture. The view of Fayolle, Gailly, \& Lassas-Clerc (2006) is that intention is a cognitive demonstration of a person's enthusiasm to display a certain behavior. Becoming an entrepreneur is a voluntary decision of an individual (Krueger, Reilly \& Carsrud, 2000). Entrepreneurial intention can be developed in an individual as a result of the incidents they face within their life (Solesvik, Westhead, \& Matlay, 2014). However, as per Brunjes \& Revilla (2013), negative events affect to create entrepreneurial intention in an individual, than positive events.

All the different models suggested by different scholars to predict entrepreneurial intention can be categorized into three categories/factors, i.e., psychological factors, family background factors and social environment factors (Peng, Lu, \& Kang, 2012). Entrepreneurial intention is a kind of mental process that is focused towards planning and managing a business (Gupta \& Bhawe, 2007). Entrepreneurial intention has been defined and measured by researchers using three factors namely, individual's attitude towards the behavior, perceived behavior, social norms and individual's self-efficacy (Krueger, Reilly, \& Carsrud, 2000). "Psychologists have proven that intentions are the best predictors of any planned behavior, particularly when the behavior is rare, hard to observe, or involves unpredictable time lags" (Krueger, Reilly, \& Carsrud, 2000, p. 411). The model "Theory of Planned Behavior" developed by Ajzen, (1991) can be used to understand the behavior of people.

Ajzen, (1991) described the considerations in guiding the human behavior in the theory that he has developed. According to the theory there are three kinds of considerations. Those are behavioral beliefs, normative beliefs and control beliefs. Behavioral beliefs are the beliefs about the likely outcomes of the behavior and the evaluations of these outcomes. Normative beliefs are the beliefs about the normative expectations of others and motivation to comply with these expectations, and control beliefs are the beliefs about the presence of factors that may facilitate or impede performance of the behavior and the perceived power of these factors. The fundamental of the TBP is the individuals' intention to perform specific behavior. Stronger the intention to perform means more likely to perform. The behavioral beliefs create favorable or unfavorable attitude toward the behavior; normative beliefs produce the perceived social pressure or subjective norm; and control beliefs grant rise to perceived behavioral control. Attitude towards the behavioral norm, subjective norm, and perception of behavioral control together, lead to the formation of a behavioral intention.

Personal attitudes refer to the positive or negative value of individual perception in becoming entrepreneur (Ajzen, 2001) whereas subjective norm is the expression of the pressure from social environment whether to carry out or not to carry out entrepreneurial behavior (Ajzen, 2001). Moreover, Perceived behavioral control refers to the perception on the easiness of carrying out entrepreneurial behavior (Ajzen, 2001).

In relation to several studies, researchers have found that men are more inclined towards the entrepreneurship than women (Crant, 1996). According to Quan, (2012) entrepreneurial intentions of males are higher than those of women, whether it is measured in terms of impulsive intention or deliberate intention. In general, men are more optimistic and likely to take more risk than women. Moreover in the decision process of creating a firm, gender is an important predictor (Delmar \& Davidson, 
2000). As per the finding of the (Sampedro, Fernandez-Laviada, \& Crespo, 2014), man's entrepreneurial intention is powerfully influenced by the subjective norm and perceived advantages. In a study of Kourilsky \& Walstad, (1998) using 1000 American teenagers, it was found that entrepreneurial inclination among females is significantly lower than the males. The percentage of the female and male intention to become an entrepreneur respectively, is $62 \%$ versus $72 \%$. Further, entrepreneurial inclination is high within the men who are having entrepreneurial family background than the women having entrepreneurial family background (Matthews \& Moser, 1996).

Based on above evidences, I formed the following 4 hypotheses.

H1: There is a difference in the impact of personal attitude on entrepreneurial intention of male and female undergraduates.

H2: There is a difference in the impact of subjective norm on entrepreneurial intention of male and female undergraduates.

H3: There is a difference in the impact of perceived behavioral control on entrepreneurial intention of male and female undergraduates.

H4: There is a statistically significant difference on entrepreneurial intention between male and female undergraduates

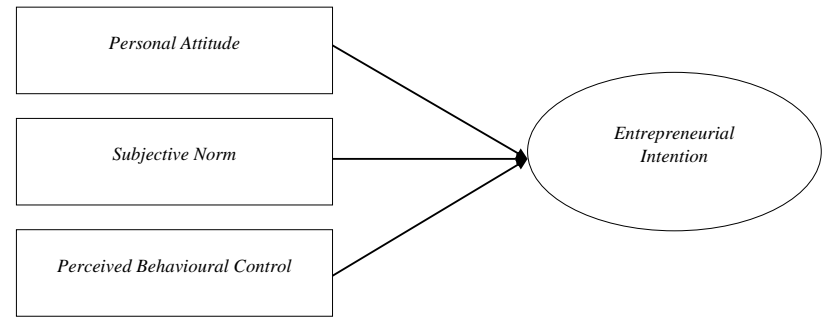

Figure 1 Conceptual Framework

\section{Research Methodology}

The study is a cross sectional study carried out in quantitative approach where Sri Lankan undergraduates were studying. There has been no interference with the results of the study as the events were studied as they occurred. The unit of analysis of the study was the undergraduates in Sri Lankan government universities.

Population of the study is undergraduates in 15 Sri Lankan government universities. Due to the difficulty of studying all undergraduates of 15 universities, initially 300 undergraduates from 3 universities namely, University of Colombo, University of Kelaniya and University of Sri Jayawardanapura were selected for the samples using stratified random sampling method. Male and female groups were considered as the two starters. From each university, 50 males and 50 females were selected for the sample. At the end of the data collection, I was able to collect only 239 questionnaires and response rate was 79.66.

Self-administered questionnaire which is developed by the Linan and Chen, (2009) is used as the data collection instrument. Data collected by using questionnaires have been analyzed through SPSS. Both Independent sample T-test and regression analysis were used to test the hypothesis of the study and make inferences. 


\section{Statistical Analysis and Results}

In order to test hypotheses, regression analysis was conducted using the impact of three independent variables namely, personal attitude, subjective norm and perceived behavioral control and entrepreneurial intention as dependent variable. In order to find the difference of entrepreneurial intention of males and females, data set was split into two groups when performing the regression analysis. The result of regression analysis is mentioned below:

Table 2 Results of Regression Analysis

\begin{tabular}{|c|c|c|c|c|c|c|c|c|}
\hline & \multirow{2}{*}{\multicolumn{2}{|c|}{$\begin{array}{l}\text { ANOVA } \\
\text { Sig }\end{array}$}} & \multirow{2}{*}{\multicolumn{2}{|c|}{$\begin{array}{c}\text { Model Summary } \\
\text { R Square }\end{array}$}} & \multicolumn{4}{|c|}{ Coefficients } \\
\hline & & & & & \multicolumn{2}{|c|}{$\mathrm{B}$} & \multicolumn{2}{|c|}{ Sig } \\
\hline & Male & Female & Male & Female & Male & Female & Male & Female \\
\hline $\begin{array}{l}\text { Model Personal } \\
\text { Attitude }\end{array}$ & 0.000 & 0.000 & 0.747 & 0.719 & 0.686 & 0.336 & 0.000 & 0.000 \\
\hline Subjective Norm & & & & & -0.043 & -0.023 & 0.042 & 0.010 \\
\hline $\begin{array}{c}\text { Perceived } \\
\text { Behavioral } \\
\text { Control }\end{array}$ & & & & & 0.355 & 0.705 & 0.000 & 0.000 \\
\hline
\end{tabular}

Source: Research Data

As per the above table, overall model of the study is significant under the $5 \%$ significance level. The $\mathrm{R}$ square value of the model depicts predictability of dependent variable by all independent variables together. In this study, R2 value of male model is 0.747 , where the IVs of this model are able to predict more than $74 \%$ of variation in entrepreneurial intention of male. Further, in the female model R2 value is 0.719 where IVs depict a $72 \%$ variation in entrepreneurial intention of female.

Moreover, IVs of the study, personal attitude, subjective norm and perceived behavioral control are significantly impacting on the entrepreneurial intention of both male and female. However, there is a difference between the impact of those three factors on the entrepreneurial intention of males and females. According to the above table, $1 \%$ change in personal attitudes affects $68.6 \%$ change in males' entrepreneurial intention while $1 \%$ change in personal attitude affects $33.6 \%$ change in females' entrepreneurial intention. The difference between impact of personal attitude on males' and females' entrepreneurial intention is $35 \%$. When considering the effect of subjective norm on entrepreneurial intention, it is identifiable that the impact is negative on both males and females. The difference between the impact of subjective norm on males' and females' entrepreneurial intention is $2 \%$. Yet, the impact of perceived behavioral control on females' entrepreneurial intention is greater than males', i.e., $35 \%$.

Afterwards, independent sample t-test was performed to test the last hypothesis of the study. There is a statistically significant difference on entrepreneurial intention between male and female undergraduates. The results of the independent sample ttest are shown in tables 3 and 4. 
Table 3 Summary of Independent Sample t-Test

\begin{tabular}{|l|c|}
\hline & Sig. (2-tailed) \\
\hline Equal variances assumed & 0.000 \\
\hline Equal variances not assumed & 0.000 \\
\hline
\end{tabular}

Source: Research Data

Table 4 Summary of Hypothesis

\begin{tabular}{|c|c|c|c|c|c|}
\hline No. & Hypothesis & \multicolumn{3}{|c|}{ Reason } & Accepted/Rejected \\
\hline \multirow{4}{*}{$\mathrm{H} 1$} & \multirow{4}{*}{$\begin{array}{l}\text { There is a difference in the impact of personal attitude on } \\
\text { entrepreneurial intention of male and female undergraduates. }\end{array}$} & \multirow{2}{*}{ Male } & B & 0.686 & \multirow{4}{*}{ Accepted } \\
\hline & & & $\mathrm{Sig}$ & 0.000 & \\
\hline & & \multirow{2}{*}{ Female } & B & 0.336 & \\
\hline & & & Sig & 0.000 & \\
\hline \multirow{4}{*}{$\mathrm{H} 2$} & \multirow{4}{*}{$\begin{array}{l}\text { There is a difference in the impact of subjective norm on } \\
\text { entrepreneurial intention of male and female undergraduates. }\end{array}$} & \multirow{2}{*}{ Male } & B & -0.043 & \multirow{4}{*}{ Accepted } \\
\hline & & & $\mathrm{Sig}$ & 0.042 & \\
\hline & & \multirow{2}{*}{ Female } & B & \begin{tabular}{|l|}
-0.023 \\
\end{tabular} & \\
\hline & & & Sig & 0.010 & \\
\hline \multirow{4}{*}{$\mathrm{H} 3$} & \multirow{4}{*}{$\begin{array}{l}\text { There is a difference in the impact of perceived behavioral } \\
\text { control on entrepreneurial intention of male and female } \\
\text { undergraduates. }\end{array}$} & \multirow{2}{*}{ Male } & B & 0.355 & \multirow{4}{*}{ Accepted } \\
\hline & & & $\mathrm{Sig}$ & 0.000 & \\
\hline & & \multirow{2}{*}{ Female } & B & 0.705 & \\
\hline & & & Sig & 0.000 & \\
\hline & $\begin{array}{l}\text { There is a statistically significant difference on } \\
\text { entrepreneurial intention between male and female } \\
\text { undergraduates. }\end{array}$ & & Sig & 0.000 & Accepted \\
\hline
\end{tabular}

\section{Managerial Implications}

In entrepreneurship literature, behavioral differences of male and female groups continue to remain a topic of ongoing debate. Is there actually a difference in entrepreneurial behavior of male and female? Therefore, this study is intended to find the difference between entrepreneurial intention of male and female undergraduates in Sri Lankan government universities. Different studies have used different theories in studying entrepreneurial intention like "theory of planned behavior, entrepreneurial event model and many other factors like education, culture, social networks" (Ranwala \& Dissanayake, 2016, p. 91). Current study used the Theory of Planned behavior as the theory to study entrepreneurial intention as it is a well-established theory to predict about the behavioral intention of people.

In the present study, the difference of gender was the main consideration. Three predictors of the behavior, as in the theory of planned behavior, perceived attitude, subjective norm and perceived behavioral control, are considered as independent variables of the study and entrepreneurial intention as the dependent variable.

In order to make inferences, I have carried out a regression analysis and an independent sample t-test. Based on those two analyses, hypotheses of the study are tested and all the hypotheses were accepted based on the results. In agreeing with Zhao, Seibert, \& Hills, (2005) current study also concluded that entrpreneurial intention of males and females is different from each other. Even though, both males 
and females are having same level of eduction to become an entrepreneur, their gender is a matter. Further, the impact of personal attitiude, subjective norm and percived behavioural control is also diferent from male to female.

With the inferences of the study, education sector can identify the reason for the gap between the expectation and the relatiy. Through this study, educationists can take mesures to encourage undergraduates to become entrepreneurs as reuired. As idnetified by the current study, in oder to motivate female undergradutes to become entrepreneurs throug the education, they need to be informed and trained about carrying out a venture is an easy task. For male undergraduates, it is needed to cultivate a positive attidute in them on entrepreneurship to make them future entrepreneurs.

\section{References}

1. Ajzen, I. (1991). The Theory of Planned Behavior. Organizational Behavior and Human Decision Processes.

2. Ajzen, I. (2001). Nature and operation of attitudes. Annual review of psychology, 27-58.

3. Bird, B. (1988). Implementing entrepreneurial ideas: The case for intention. Academy of Management Review, Vol 13.

4. Bird, B., \& Brush, C. G. (2002). A gendered perspective on organizational creation. Entrepreneurship Theory \& Practice, 41-65.

5. Brunjes, J., \& Revilla, J. (2013). 'Recession push' and 'prosperity pull' entrepreneurship in a rural developing context. Entrepreneurship and Regional Development, 115-123.

6. Brush, C. G. (2006). Women entrepreneurs: A research overview. In The Oxford handbook of entrepreneurship.

7. Crant, J. M. (1996). The proactive personality scale as a predictor of entrepreneurial intentions. J Small Bus Manage, Vol 34.

8. De Vita, L., Mari, M., \& Poggesi, S. (2014). Women entrepreneurs in and from developing countries: Evidences from the literature. European Management Journal, 451-460.

9. Delmar, F., \& Davidsson, P. (2000). Where do they come from? Prevalence and characteristics of nascent entrepreneurs. Entrepreneurship and Regional Development, Vol 12.

10. Diaz-Garcia, M. C., \& Jimenez-Moreno, J. (2009). Entrepreneurial intention: the role of gender. International Entrepreneurship and Management Journal, 261283.

11. (2018). Economic Statistics of Sri Lanka 2018. Colombo: Department of Census \& Statistics, Ministry of National Policies \& Economic Affairs, Sri Lanka.

12. Edirisinghe, S. D., \& Nimeshi, G. S. (2016). Entrepreneurial Inclination among University Students: With Special Reference to University of Kelaniya, Sri Lanka. Journal of Business and Management, 7-12.

13. Fagenson, E. A., \& Marcus, E. C. (1991). Perceptions of the sex-role stereotypic characteristics of entrepreneurs: women's evaluations. Entrepreneurship Theory \& Practice, 33-47.

14. Fayolle, A., Gailly, B., \& Lassas-Clerc, N. (2006). Assessing the impact of entrepreneurship education programmes: A new methodology. Journal of European Industrial Training, Vol 30(9). 
15. Ferreira, J. J., Raposo, M. L., Rodrigues, R. G., Dinis, A., \& Do Paco, A. (2012). A model of entrepreneurial intention: An application of the psychological and behavioral approaches. Journal of Small Business and Enterprise Development, 78-88.

16. Ferri, L., Ginesti, G., Spanò, R., \& Zampella, A. (2018). Exploring the Entrepreneurial Intention of Female Students in Italy. Journal of Open Innovation: Technology, Market, and Complexity, 1-10.

17. (2018). Global Entrepreneurship Monitor. Global Entrepreneurship Research Association.

18. Gupta, V. K., \& Bhawe, N. W. (2007). The influence of proactive personality and stereotype threat on women's entrepreneurial intentions. Journal of Leadership \& Organizational Studies, Vol 13.

19. Gupta, V. K., Turban, D. B., Wasti, S. A., \& Skidar, A. (2009). The role of gender stereotypes in perceptions of entrepreneurs and intentions to become an entrepreneur. Entrepreneurship Theory \& Practice, 397-417.

20. Kourilsky, M. I., \& Walstad, W. B. (1998). Entrepreneurship and female youth: Knowledge, attitudes, gender differences, and educational practices. Journal of Business Venturing, 13-26.

21. Krueger, N. F., Reilly, M. D., \& Carsrud, A. L. (2000). Competing models of entrepreneurial intentions. Journal of Business Venturing, Vol 15.

22. Langowitz, N., \& Minniti, M. (2007). The entrepreneurial propensity of women. Entrepreneurship Theory \& Practice, 211-224.

23. Linan, F., \& Rodriguez-Cohard, J. C. (2015). Assessing the stability of graduates' entrepreneurial intention and exploring its predictive capacity. Academia Revista Latinoamericana de Administración, Vol 28.

24. Loscocco, K., Monnat, S. M., Moore, G., \& Lauber, K. B. (2009). Enterprising women: A comparison of women's and men's small business networks. Gender \& society, 388-411.

25. Matthews, C. H., \& Moser, S. B. (1996). A longitudinal investigation of the impact of family background and gender on interest in small firm ownership. Journal of Small Business Management, Vol 34.

26. Peng, Z., Lu, G., \& Kang, H. (2012). Entrepreneurial Intentions and Its Influencing Factors: A Survey of the University Students in Xi'an China. Creative Education, Vol 3.

27. Perera, Q. (2012, May 06). Local universities producing less than 5\% of SL's entrepreneurs. Retrieved December 25, 2012, from Sunday Times: http://www.sundaytimes.lk/120506/BusinessTimes/bt16.html

28. Quan, X. (2012). Prior experience, social network, and levels of entrepreneurial intentions. Management Research Review, Vol 35(10).

29. Ranwala, R. S., \& Dissanayake, D. (2016). Big five personality traits and entrepreneurial inclination: A study based on Sri Lankan undergraduates. Social and Basic Science Review, 84-98.

30. Sampedro, I. R., Fernandez-Laviada, A., \& Crespo, A. H. (2014). Entrepreneurial intention: perceived advantages and disadvantages. Academia Revista Latinoamericana de Administración, 11-25.

31. Shinnar, R. S., Giacomin, O., \& Janssen, F. (2012). Entrepreneurial Perceptions and Intentions: The Role of Gender and Culture. Entrepreneurship Theory and Practice, 465-493. 
32. Solesvik, M., Westhead, P., \& Matlay, H. (2014). Cultural factors and entrepreneurial intention: The role of entrepreneurship education. Education + Training, Vol 56(8/9).

33. Verheul, I., Thurik, R., Grilo, I., \& van der Zwan, P. (2012). Explaining preferences and actual involvement in self-employment: gender and the entrepreneurial personality. Journal of Economic Psychology, Vol 33.

34. Welter, F. (2011). Contextualizing entrepreneurship-conceptual challenges and ways forward. Entrepreneurship Theory \& Practice, Vol 35.

35. Wilson, F., Kickul, J., \& Marlino, D. (2007). Gender, entrepreneurial selfefficacy, and entrepreneurial career intentions: implications for entrepreneurship education. Entrepreneurship Theory \& Practice, 56-71.

36. Zhang, Z., Zyphur, M. J., Narayanan, J., Arvey, R. D., Chaturvedi, S., \& Avolio, B. J. (2009). The genetic basis of entrepreneurship: effects of gender and personality. Organizational Behavior and Human Decision Processes, 67-89.

37. Zhao, H. S., Seibert, S. E., \& Hills, G. E. (2005). The mediating role of selfefficacy in the development of entrepreneurial intentions. Journal of Applied Psychology, 189-202.

\section{About Our Author}

Randini S. Rnawala is a lecturer (Probationary) at University of Kelaniya. She is a young researcher interested in the field of entrepreneurship. She has already done few researches in entrepreneurship and is interested in resourcing on entrepreneurial intention, entrepreneurship education, female entrepreneurship and green entrepreneurship. 